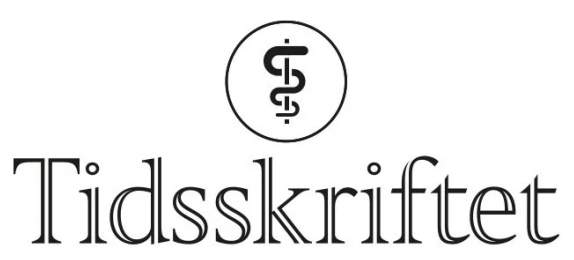

DEN NORSKE LEGEFORENING

\title{
Rastløse bein og kirurgi
}

\author{
KOMMENTAR \\ EINAR KINGE \\ einar@kinge.eu \\ Einar Kinge er spesialist i nevrologi ved Sandvika Nevrosenter - Avtalespesialistene. \\ Forfatteren har ikke oppgitt noen interessekonflikter.
}

Arvesen og Zahl kommenterer i Tidsskriftet nr. 18/2021(1) Bjorvatn og medarbeideres

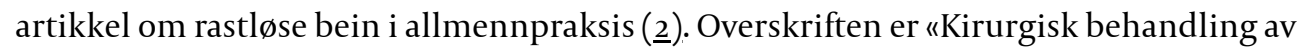
rastløse bein er utbredt og effektivt». Påstanden bygger på egne kliniske erfaringer og litteraturreferanser. Senere modifiseres utsagnet i overskriften til at «det er god dekning for å anbefale at pasienter med rastløse bein og overfladisk venøs insuffisiens behandles med metoder som endovenøs laserablasjon (EVLA) etter påvisning av venøs insufficiens med fargedupleks, altså ultralyd som avdekker venøs refluks». Det siste er viktig og burde fremkomme i overskriften. Det er ingen evidens for at kirurgisk behandling av pasienter med rastløse bein uten venøs insufficiens har effekt.

Rastløse bein er en nevrologisk lidelse med uro og ubehag i beina der fem følgende diagnostiske kriterier skal være oppfylt (3):

1. Et påtrengende behov for å bevege beina, vanligvis ledsaget av ubehagelige følelser $\mathrm{i}$ beina

2. Symptomene forverres ved hvile og inaktivitet

3. Symptomene opphører helt eller delvis ved bevegelse av beina

4. Symptomene forverres om kvelden eller natten

5. Symptomene har ingen annen åpenbar forklaring

Årsaken er ikke avklart, men skyldes trolig dysfunksjon i sentralnervesystemet (4.). Det er ikke holdepunkter for at den nevrologiske lidelsen rastløse bein skyldes venøs insufficiens. Siden både venøs insufficiens og rastløse bein er vanlige tilstander, er det å anta at komorbiditet forekommer. Pasienter med uttalte symptomer på rastløse bein kan også ha tilsvarende symptomer fra armene, noe som vanskelig kan ses å ha sammenheng med venøs insuffisiens i beina.

Selv om venøs insufficiens og rastløse bein har kliniske fellestrekk er det viktig å forstå at det dreier seg om to forskjellige tilstander med forskjellig patofysiologi og symptombilde, som skal behandles ulikt. Pasienter med rastløse bein har først og fremst bevegelsestrang 
og bevegelseslindring. Klinisk finner man ikke nevrologiske utfall. Pasienter med venøs insufficiens har objektive funn. Det er viktig slik som Arvesen og Zahl påpeker, at pasienter med uavklarte symptomer fra beina gjennomgår grundig utredning.

Det finnes imidlertid ingen nyere fagfellevurderte publiserte studier om effekt av kirurgi på rastløse bein. Inntil videre har vi ingen holdepunkter for å anbefale at pasienter med rastløse bein uten objektive tegn på venøs insufficiens skal opereres.

\section{LITTERATUR}

1. Arvesen A, Zahl PH. Kirurgisk behandling av rastløse bein er utbredt og effektivt. Tidsskr Nor Legeforen 2021; 141. doi:10.4045/tidsskr.21.0815. [PubMed][CrossRef]

2. Bjorvatn B, Wensaas KA, Emberland KE et al. Rastløse bein - en studie fra allmennpraksis. Tidsskr Nor Legeforen 2021; 141. doi: 10.4045/tidsskr.21.0333. [PubMed][CrossRef]

3. Allen RP, Picchietti DL, Garcia-Borreguero D et al. Restless legs syndrome/Willis-Ekbom disease diagnostic criteria: updated International Restless Legs Syndrome Study Group (IRLSSG) consensus criteria-history, rationale, description, and significance. Sleep Med 2014; 15: 860-73. [PubMed] [CrossRef]

4. Kinge E, Ulfberg J. Søvnrelaterte bevegelsesforstyrrelser. Tidsskr Nor Legeforen 2009; 129: 1888-91. [PubMed][CrossRef]

Publisert: 14. februar 2022. Tidsskr Nor Legeforen. DOI: 10.4045/tidsskr.22.0062

(C) Tidsskrift for Den norske legeforening 2023. Lastet ned fra tidsskriftet.no 26. april 2023. 